\title{
Examining the Relationship between Pre-Service Teachers' Critical Thinking Disposition, Problem Solving Skills and Teacher Self-Efficacy
}

\author{
Ramazan Cansoy ${ }^{1} \&$ Muhammet Emin Türkoğlu ${ }^{2}$ \\ ${ }^{1}$ Karabük University, Faculty of Letters, Department of Educational Sciences, Karabuk, Turkey \\ ${ }^{2}$ Afyon Kocatepe University, Faculty of Education, Ahmet Necdet Sezer Campus, Afyonkarahisar, Turkey \\ Correspondence: Muhammet Emin Türkoğlu, Afyon Kocatepe University, Faculty of Education, Ahmet Necdet \\ Sezer Campus, Afyonkarahisar, Turkey. E-mail: eminturkoglu@gmail.com
}

Received: January 5, 2017

doi:10.5539/ies.v10n6p23

\begin{abstract}
The aim of this study was to examine the relationships between the pre-service teachers' critical thinking disposition, problem-solving skills and self-efficacy beliefs. The participants of the study were 519 pre-service teachers from Afyon Kocatepe University, Education Faculty. Critical Thinking Disposition, Problem Solving Inventory, and Teacher Self-efficacy Scale were used to collect the data. Arithmetic mean, Pearson Product-Moment Correlation Coefficient and Multiple Linear Regression Analysis were employed in data analysis. The results of the study revealed that the pre-service teachers' critical thinking disposition was low, problem-solving skills were moderate and teacher self-efficacy perceptions were quite adequate. However, the critical thinking disposition and problem-solving skills revealed significant positive correlations with all dimensions of teacher self-efficacy. An important finding is that critical thinking disposition and problem-solving skills were positive and significant predictors of all sub-dimensions of teacher self-efficacy beliefs.
\end{abstract}

Keywords: self-efficacy, critical thinking, problem-solving skills, pre-service teachers

\section{Introduction}

Teacher self-efficacy beliefs are teachers' beliefs on how learners can learn and improve their achievements (Bergman, McLaughlin, Bass, Pauly, \& Zellman, 1977; Ruble, Usher, \& McGrew, 2011). The high level of teachers' self-efficacy perceptions leads to positive changes in many educational outcomes. In this context, it is seen that teachers' beliefs about their own qualifications make them increase the quality of education and overcome the problems they encounter (Main \& Hammond, 2008; Özerkan, 2007; Tschannen-Moran, A. W. Hoy, \& W. K. Hoy, 1998; Woolfolk \& Hoy, 1990). Results of positive developments in self-efficacy led to improvements in education and training, which gave rise to investigation of this concept in relation to different concepts. Critical thinking disposition and problem-solving skills are among these concepts. There are a number of studies investigating the relationship between critical thinking skills and self-efficacy (Zangenehvandi, Farahian \& Gholami, 2014; Kezer, Oğurlu, Akfirat, 2016; Manalo, Kusumi, Koyasu, Michita \& Tanaka, 2013; Phan, 2009; Srisawad, Ratanaolarn \& Kiddee, 2016; Varandi, Mehrali, 2013;Dehghani, Pakmehr \& Malekzadeh, 2011) and relationship between problem solving skills and self-efficacy (Altunçekiç, Yaman, Koray, 2005; Aylar \& Aksin, 2011; Kesicioğlu \& Güven, 2014; Yenice, 2012). These studies show that critical thinking disposition and problem-solving skills are related to self-efficacy of teachers. However, studies on the predictive power of problem-solving and critical thinking disposition over self-efficacy tend to be limited (Kesicioğlu \& Güven, 2014; Zangenehvandi, Farahian, \& Gholami, 2014). Problem solving is to overcome a difficulty and critical thinking is to find the ideas to overcome these difficulties (Seferoğlu \& Akbıyıkık, 2006). Exposing the predictive power of problem-solving skills and critical thinking disposition over self-efficacy of teachers may contribute to determining effective policies for problem solving and the development of critical thinking disposition. In addition, this study can provide researchers with an insight into individual characteristics that explain self-efficacy. For this reason, the relationship between critical thinking, problem-solving skills and self-efficacy, and predictive power of critical thinking and problem solving skills as independent variables on 
self-efficacy of teachers has been discussed in this study.

Critical thinking and problem solving are thinking skills, and thus, they require cognitive processes (Beyer, 1988; Özden, 2000). The common point of thinking skills is problem solving and decision making (Beyer, 1988). Problem-solving is thinking critically and producing a solution by processing information (Seferoğlu \& Akbıyık, 2006). Gathering and encoding of data related to an event, explaining a problem with similarities and differences, formulating a solution plan, using knowledge and principles, and evaluating possible solutions require cognitive processes (Kapa, 2001). Cognitive processing ability can be said to be an important factor in an individual's performance when treated as his/her ability to process complex information (Truxillo, Seitz \& Bauer, 2008). Thinking about ideas, being aware of ideas, performance, memory and competence acquisition are among fundamental elements in problem solving (Hudlicka, 2005). The ability of individuals to perform a job successfully is due to their cognitive processing (Chen, Casper \& Cortina, 2001; Cormier, Pickett-Hauber \& Whyte, 2010). In the development of self-efficacy, it is important that individuals can use their own cognitive strategies and manage themselves in different dimensions (Chemers, Hu \& Garcia, 2001). One of the core competences of self-efficacy is to operate cognitive processes to predict problems and decide how to deal with them (Bandura, 1989). Cognitive processes can lead to an increase in the level of self-efficacy by learning how to behave in difficult, complex and unexpected situations to deal with them using critical thinking (Gloudemans, Schalk \& Reynaert, 2013). A good level of adaptation to problem-solving processes helps to better manage the work and achieve goals more easily (Bandura, 1986). Besides, high levels of self-efficacy can facilitate individuals' solving their problems (Bandura, 1977), and in this respect, solving problems is influential in path to success in their life (Belzer, D'Zurilla \& Maydeu-Olivares, 2002).

\subsection{Critical Thinking Disposition}

Critical thinking refers to individuals' questioning their thoughts on a rational basis, and reflecting and thinking reasonably by focusing on decision making (Ennis, 1962). Critical thinking can be expressed to show the accuracy and certainty of knowledge (Beyer, 1987). It is the refinement and orientation of thought in a particular systematicity, and the realization of thinking in a logical framework (Paul \& Elder, 2008). Critical thinking is to make individuals be aware of their thoughts, evaluate them, interpret the thought processes of others (Cüceloğlu, 1994), rate a problem in terms of validity and consistency by using certain standards in understanding and analyzing the problem (Kazanc1 1989). Critical thinking occurs when one thinks about his/her own thinking by providing standards of clarity, accuracy, importance and relevance, proficiency, depth, breadth, and certainty (Nosich, 2012). In other words, critical thinking emphasizes the ability to understand the thoughts, make sense of the ideas, and make logical decisions.

Critical thinking has some peculiar features. It requires that people think about their own thinking. They must judge their own ideas that meet certain logic criteria, deal with real problems, and evaluate certain rules in a logical framework. Asking questions, solving questions and analyzing problems are important criteria in critical thinking. The main goal is to think and solve the problem instead of making negative conclusions (Nosich, 2012). It can be said that the basis of critical thinking is important in terms of evaluating, interpreting and considering different perspectives on the issues considered in the application of different features of thinking.

Critical thinking skills and critical thinking disposition are among the topics covered under the concept of critical thinking. Disposition and skill are two interrelated concepts. Critical thinking includes concepts of skill and disposition (Dam \& Volman, 2004; Facione, 1990). Critical thinking skills refers to the ability to think critically through certain mental methods. Critical thinking disposition is the desire and motivation of the individual to think critically (Zhang, 2003). Critical thinking disposition is to make decisions and solve problems in accordance with consistent internal motivations (P. A. Facione, N. C. Facione, \& Giancarlo, 1996). Critical thinking disposition is necessary for critical thinking skills (Norris, 1994). It can thus be stated that these two concepts cannot be separated from each other by clear lines, but have a pattern in the context of cause and effect.

Critical thinking disposition can be dealt with in different dimensions. Ennis (1985) refers to critical thinking disposition as searching for the cause, using reliable data, looking at the problem holistically, focusing on the main problem, putting together complex parts and being open-minded. According to Tishman, Jay and Perkins (1993), critical thinking disposition is to be open-minded, find problems, conceptualize problems, plan and develop strategies, understand, seek the truth, work and reflect on mental processes. Tishman, Jay and Perkins (1993) describe critical thinking disposition as being open-minded, finding problems, conceptualising problems, developing plans and strategies, understanding, realizing, and working with mental processes. The critical thinking disposition in the context of this study is expressed by P. A. Facione, N. C. Facione, and Giancarlo (1996) as being analytical, systematic and open-minded, having cognitive maturity, curiosity and self-confidence, 
and searching for truth. Analyticity is the preparation for problems that may arise, identifying the causes and using the necessary data for problem solving purposes. Systematicity is to be focused, resolute, organized and planned while solving a problem. Open-mindedness is about being open to different views, approaches and views, and evaluating others' views in the decision-making phase. Cognitive maturity is described as seeing the level of complexity in the problems and acting rationally. Curiosity is the excitement of learning, and learning of people who are not expecting a response. Self-confidence is a guide to the intelligence of a person and to the rational decision-making of others. The convergence of these qualities provides an overall assessment of the disposition to think critically. Searching for truth can be defined as having intellectual determination, valuing different ideas, trying to reach the right information, seeking reasons and evidence about the truth, and acting objectively against different ideas.

\subsection{Problem-Solving Skills}

A problem is a conflict situation that arises when the attainment of a goal is prevented (Morgan, 1991), the need to react to situations that interfere with balance and dissonance (D'Zurilla \& Nezu, 1987), something dissonant with internal and external demands (Heppner \& Krauskopf, 1987). It prevents individual or organizational goals from being realized for any reason (Demirtaş \& Güneş, 2002). Problem solving is concerned with thinking processes that reveal individuals' point of view when a problem occurs. In this case, problem solving can be explained by the cognitive strategies determined by individuals. At the same time, these cognitive strategies can be applied to other situations after learning them (Gagné, 1985). Individuals' thoughts, feelings and behaviors related to individual problems in everyday life are related to problem-solving skills (Heppner \& Krauskopf, 1987).

Problem-solving skills require certain qualities that are coping with problems, solving problematic situations, evaluating the cognitive processes, understanding and solving a problem completely (Heppner, Baumgardner \& Jakson, 1985; cited in Güçlü, 2003). At the same time, in solving a problem, different steps must be fulfilled. These steps can be described as follows: (i) defining the problem correctly, understanding of its structure in order to set goals for the solution, (ii) identifying as many different solution paths as possible, (iii) deciding on the most appropriate solution, (iv) implementing solution paths and evaluating the results obtained in a logical framework (Çam \& Tümkaya, 2007). Besides, problem-solving confidence, approach-avoidance and personal control are important components of problem solving skills. Problem-solving confidence is the belief in self-assurance and problem-solving competence in problem solving. Approach-avoidance is to observe problem-solving methods and evaluate different ways of solution and search for different way out. Personal control is the management of behaviors and feelings while solving a problem (Heppner \& Baker, 1997). Individuals need to have certain important competencies in order to solve problems. These competencies are as follows: (i) coping with both problem-oriented and emotion-oriented situations (ii) competencies that can identify problems and putting forth alternatives about them (iii) cognitive processes that require chain thinking, (iv) self-confidence in solving a problem (Heppner \& Baker, 1997).

\subsection{Teacher Self-Efficacy}

Self-efficacy is perceptions and beliefs of an individual about how to manage a situation, complete a task, and obtain the desired results (Bandura, 1994). Teacher self-efficacy beliefs are the beliefs of teachers about how to improve their students' learning and achievement (Bergman, McLaughlin, Bass, Pauly \& Zellman, 1977; Ruble, Usher \& McGrew, 2011). Low levels of teacher self-efficacy beliefs cause problems in the accomplishment of educational objectives (Battersby \& Cave, 2014; Henson, 2001; Tschannen-Moran \& Woolfolk-Hoy, 2001).

Personal or environmental factors seem to play a role in developing self-efficacy, which is seen as important in education. According to Bandura (1977), the first factor is individuals' believing in their competence regarding life experiences, and evaluating themselves more positively. The second factor is modeling others who have successful experiences, and applying them in life by making inferences. The third is receiving verbal encouragement and support from others to do a task. Finally, individuals' physical and emotional states can affect their self-efficacy beliefs. In this regard, self-efficacy of teachers is related to their feelings of competence in their classes (Marri, Ahn, Fletcher, Heng \& Hatch, 2012), the quality of classroom teaching (Zee \& Koomen, 2010), student behaviors, professional experience (Egyed \& Short, 2006), job satisfaction (Viel-Ruma, Houchins, Jolivette \& Benson, 2010) and accountability pressure (Ford, Sickle, Clark, Fazio-Brunson \& Schween, 2014).

According to Tschannen-Moran and Woolfolk-Hoy (2001) teacher self-efficacy is considered as a three-dimensional structure. These are efficacy for student engagement, efficacy for instructional strategies, and efficacy for classroom management. Efficacy for student engagement is a teacher's capacity to make students engage in different activities and believe in that they could manage them. Efficacy for instructional strategies 
reveals the ability of teachers to use different techniques to develop and evaluate student learning. Efficacy for classroom management refers to teacher perceptions that they can create a peaceful learning atmosphere within the classroom.

Determining the relationship between pre-service teachers' self-efficacy, critical thinking disposition and problem-solving skills, and revealing variables that predict teacher self-efficacy is of significance in terms of developing teacher self-efficacy. Pre-service teachers are thought to be more effective teachers in the future, depending on their critical thinking disposition, problem-solving skills, their beliefs about student learning and their ability to improve student achievement. In this context, the following research questions were addressed in the study.

1) What are the levels of pre-service teachers' perception of self-efficacy, critical thinking disposition and problem-solving skills?

2) Are there significant correlations between pre-service teachers' self-efficacy, critical thinking disposition, and problem-solving skills?

3) Are pre-service teachers' critical thinking disposition and problem solving skills significant predictors of teacher self-efficacy dimensions?

\section{Method}

In this section, research design, participants, instruments and data analysis are explained.

\subsection{Research Design}

This study was designed with a correlational research model to examine the relationship between pre-service teachers' critical thinking disposition, problem solving skills, and teacher self-efficacy. Dependent variables of the research are efficacy for student engagement, efficacy for instructional strategies and efficacy for classroom management, which are sub-dimensions of teacher self-efficacy. The independent variables are critical thinking disposition, and problem solving skills.

\subsection{Participants}

The participants of the research were a total of 519 pre-service teachers studying at Afyon Kocatepe University, Faculty of Education, in the 2016-2017 academic year. The average age of the participants was 20.13, 379 (73\%) were female and $140(27 \%)$ were male. One hundred eighty-six (36\%) of the participants were first-year students and $333(64 \%)$ were third-year students.

\subsection{Instruments}

A questionnaire with four sections was used to gather the data. The first section related to the demographic characteristics of the participants included gender, age, subject area and year of study. The remaining sections were the California Critical Thinking Disposition Inventory, the Problem Solving Scale, and the Teacher Self-Efficacy Scale, respectively

\subsubsection{California Critical Thinking Disposition Inventory}

This scale, which was developed by P. A. Facione, N. C. Facione, and Giancarlo (1998) and adapted to Turkish by Kökdemir (2003), measures critical thinking disposition. In the instrument consisting of 51 items and 6 sub-dimensions, a 6-point grading scale with options randing from "(1) Strongly disagree" to "(6) Strongly agree" is used. The variance explained in the whole scale is $36.13 \%$. The scale includes the dimensions of open-mindedness, self-confidence, inquisitiveness, truth-seeking, systematicity and analiticity. As the score on the inventory goes up, the level of critical thinking disposition increases. When the inventory was considered as a whole, a score less than 240 was evaluated as low, while a score higher than than 300 was evaluated as high. The evaluations for this study were based on the mean score. Therefore, a mean score of 240 points shows that individuals' critical thinking dispositions are low. The Cronbach's Alpha coefficient calculated for the scale by Kökdemir (2003) was found to be.88. This scale was used in different studies and the Alpha coefficient's reliability values of scale were. 80 and above (Kantek, Öztürk, \& Gezer, 2010; Kezer, Ogurlu, \& Akfirat, 2016). In this study, all dimensions of the scale were used in order to determine the disposition of the teacher candidates in thinking critically. The Alpha coefficient's reliability of Item 51 was very low, and when this item was excluded, the reliability was expected to increase. For this reason, this item was excluded from the analysis by looking at item-total correlations. The Cronbach's Alpha coefficient calculated for the scale in the present study was found to be.82. Sample items from the scale included: "Compulsory courses in university are a waste of time", "You can define me as a reasonable person", "It is easy for me to organize my thoughts". 


\subsubsection{Problem Solving Inventory}

This scale was developed by Heppner and Petersen (1982) and adapted to Turkish by Şahin, Şahin, and Heppner (1993). The variance explained in the scale is $50.1 \%$, and it consists of 32 items. The sub-dimensions are Reflective Approach, Evaluative Approach, Self-Reliable Approach, Planned Approach, Quick Approach, and Abstention (Skeptical) Approach. A 6-point rating scale with options ranging from "(1) Strongly disagree" to "(6) Strongly agree" is used. High scores in the scale shows that individuals perceive themselves as inadequate in problem solving skills, show avoidance-approaching behavior and do not feel personal control (Şahin, Şahin \& Heppner, 1993). Scores in the scale range between 32-192. In Şahin, Şahin and Heppner (1993), the reliability of the whole scale was found as.88. This values is reported to be above $80 \%$ in different studies (Altun, 2015; Oğuztürk, Akça, \& Şahin, 2011). In the present study, the scale was used instead of its dimensions in order to determine the problem solving skills of the pre-service teachers. The reliability coefficients of Items 3, 9, 21, and 23 were very low, and when these items were excluded, the reliability of the scale would increase. In this sense, considering the item-total correlations, these four items were excluded from the analysis which was carried out with 28 items. The Cronbach's Alpha coefficient for this scale was. 83 in this study. Sample items from the scale include: "I consider next steps when I encounter a problem", "I compare the final result with the result I have expected while solving a problem", "I am not sure that I can solve a problem when I see one".

\subsubsection{Teacher Self-Efficacy Scale.}

The scale was developed by Tschannen-Moran and Woolfolk (2001) and adapted to Turkish by Çapa, Çakıroğlu and Sarkkaya (2005). Tschannen-Moran and Woolfolk (2001) reported that the variance explained for each sub-dimension varied between $43 \%$ and $58 \%$. The scale consists of 24 items in 3 sub-dimensions. A 9-point ratins scale is used which has options ranging from "(1) Insufficient" to "(9) Very good". Low scores in the scale indicate low competence perception, whereas high scores indicate high perception of competence. The dimensions of the scale are (1) efficacy for student engagement, (2) efficacy for instructional strategies, and (3) efficacy for classroom management. There are 8 items in each dimension. Çapa, Çakıroğlu and Sarıkaya (2005) reported the Cronbach's Alpha coefficients as.82 for efficacy for student engagement,.86 for efficacy for instructional strategies,.84 for efficacy for classroom management, and.93 for the whole scale. When reliability of the scale was tested for the present study, Cronbach's Alpha coefficient was found to be. 86 for efficacy for student engagement,.89 for efficacy for instructional strategies and.88 for efficacy for classroom management. The reliability value of the whole scale was .95 . Sample items for these dimensions are as follows: (efficacy for student engagement) "How much can you do to get through the most difficult students?", (efficacy for instructional strategies) "How well can you respond to difficulty questions from your students?" and (efficacy for classroom management) "How well can you respond to defiant students?".

\subsection{Analysis of Data}

The data were first examined for missing or incorrect values, outliers and multiple changes. The research questions were then analyzed. First, missing values were determined and average values were assigned to them. Multi-collinearity, VIF, tolerance values were examined for the relationships between the variables. There were no tolerance near zero and no VIF higher than 10 according to the analysis. Correlation values between predictor variables were examined. Correlations between predictor variables were found to be lower than.70. When assessed together with other assumptions, it was seen that there was no multi-collinearity problem. If the tolerance value is less than 20 , the VIF value is greater than 10 , the CI value is higher than 30 , and correlations between the independent variables are. 80 and above, multicollinearity may be in play (Büyüköztürk, 2010). The values of skewness and kurtosis of the data were between -1 and +1 or they had close values. It can be said that data are close to or far from normal distribution depending on whether the skewness and kurtosis values are between $(+1)$ and (-1) (SSencan, 2005). Hence, it can be stated that the data of this study was close to normal. In the analysis of the research questions, the arithmetic mean of the scores obtained from critical thinking disposition, problem solving and teacher self-efficacy scale were calculated. Pearson Product-Moments correlation coefficient (r) was used to determine relationships between the variables. In critical thinking disposition, as the scale score increases, critical thinking disposition also increases. On the other hand, in problem solving skills, as the scale score increases, the perception of competence to solve problems decreases. In this respect, the negative relationship between these two scales suggests that problem-solving skills will actually increase with critical thinking disposition. Multiple Linear Regression Analysis was performed to determine the predictive power of critical thinking disposition and problem solving skills over teacher self-efficacy. In the analyses, critical thinking disposition and problem-solving skills were predictor variables while teacher self-efficacy was the predicted variable. In interpreting the regression analyzes, the standardized Beta $(\beta)$ coefficients and t-test results were examined for their significance. The significance level was set at.05 in the 
analyses.

\section{Results}

In this section, mean and standard deviation values of pre-service teachers' critical thinking disposition, problem solving skills and teacher self-efficacy perceptions are presented. These are followed by the results of correlation and regression analyses.

\subsection{Means, Standard Deviations and Correlations between the Variables}

In Table 1, means, standard deviations, and correlations between the variables are presented.

Table 1. Correlation matrix for critical thinking disposition, problem-solving skills and teacher self-efficacy

\begin{tabular}{lcccccccc}
\hline Variables & $\bar{X}$ & $\mathrm{~S}$ & 1 & 2 & 3 & 4 & 5 & 6 \\
\hline 1. Critical thinking disposition & 216.27 & 20.79 & 1 & & & & & \\
2. Problem solving skills & 122.82 & 15.00 & $.67^{* *}$ & 1 & & & & \\
3. Efficacy for student engagement & 54.64 & 8.79 & $.39^{* *}$ & $.39^{* *}$ & 1 & & & \\
4. Efficacy for instructional strategies & 54.14 & 9.51 & $.41^{* *}$ & $.39^{* *}$ & $.82^{* *}$ & 1 & & \\
5. Efficacy for classroom management & 54.61 & 9.42 & $.33^{* *}$ & $.38^{* *}$ & $.77^{* *}$ & $.79^{* *}$ & 1 & \\
6. Whole scale [teacher self- efficacy] & 163.39 & 25.82 & .40 & .42 & .93 & .94 & .92 & 1 \\
\hline$* * p<.05$ & & & & & & & & \\
\hline
\end{tabular}

As is seen in Table 1, the mean score of the pre-service teachers' critical thinking disposition was 216.27. A score lower than 240 means a low level of critical thinking disposition. Therefore, the teachers' critical thinking disposition was low. Their mean score of problem-solving skills was 122.82. High scores from problem solving skills show that individuals perceive their problem-solving skills at a moderate level. The pre-service teachers' mean scores in efficacy for student engagement, efficacy for instructional strategies and efficacy for instructional strategies, which are the dimensions of teacher self-efficacy, were 54.64, 54.14 and 54.61, respectively. The mean score of the whole scale was 163.39. The pre-service teachers' self-efficacy scores were found to be close to one another. The low score from the scale indicates low efficacy perception, whereas the high score indicates high perception of efficacy. The pre-service teachers perceived themselves at a fairly adequate level in self-efficacy considering their scores from the scale and its dimensions.

Table 1 shows the relationship between critical thinking disposition, problem solving skills and teacher self-efficacy of pre-service teachers. There was a significant positive relationship $(r=.67, p<.05)$ between pre-service teachers' critical thinking disposition and problem solving skills. As the critical thinking disposition increases, the level of problem solving skills increases. Critical thinking disposition positively correlated with efficacy for student engagement $(r=.39, p<.05)$, efficacy for instructional strategies $(r=.41, p<.05)$, and efficacy for classroom management $(r=.33, p<.05)$. Teacher self-efficacy positively correlated with critical thinking disposition $(r=.40, p<.05)$. Problem solving skills positively correlated with efficacy for student engagement $(r$ $=.39, p<.05)$, efficacy for instructional strategies $(r=.39, p<.05)$, and efficacy for classroom management $(r$ $=.38, p<.05)$. Teacher self-efficacy (all dimensions) positively correlated with problem solving skills $(r=.42, p$ $<.05)$.

\subsection{Predictors of Teacher Self-Efficacy}

The results of multiple linear regression analysis predicting teacher self-efficacy by critical thinking disposition and problem solving skills are given in Table 2. 
Table 2. Results of regression analysis predicting teacher self-efficacy

\begin{tabular}{|c|c|c|c|c|c|c|c|c|c|c|c|c|}
\hline \multicolumn{13}{|c|}{ Teacher self-efficacy dimensions } \\
\hline \multirow{2}{*}{ Variables } & \multicolumn{3}{|c|}{ Student engagement ${ }^{\mathrm{a}}$} & \multicolumn{3}{|c|}{ Instructional strategies $^{\mathrm{b}}$} & \multicolumn{3}{|c|}{ Classroom management $^{\mathrm{c}}$} & \multicolumn{3}{|c|}{ Whole scale $^{\mathrm{d}}$} \\
\hline & $\beta$ & $\mathrm{t}$ & $\mathrm{p}$ & $\beta$ & $\mathrm{t}$ & $\mathrm{p}$ & $\beta$ & $\mathrm{t}$ & $\mathrm{p}$ & $\beta$ & $\mathrm{t}$ & $\mathrm{p}$ \\
\hline Constant & & 6.62 & .00 & & 5.33 & .00 & & 7.60 & .00 & & 4.27 & .00 \\
\hline $\begin{array}{c}\text { Critical thinking } \\
\text { disposition }\end{array}$ & .23 & 4.33 & .00 & .26 & 4.93 & .00 & .13 & 2.55 & .01 & 0.22 & 4.28 & .00 \\
\hline \multirow[t]{4}{*}{ Problem solving skills } & .23 & 4.38 & .00 & .21 & 4.06 & .00 & .29 & 5.42 & .00 & 0.26 & 5.05 & .00 \\
\hline & \multicolumn{3}{|c|}{${ }^{\mathrm{a}} R=.42$} & \multicolumn{3}{|c|}{${ }^{\mathrm{b}} R=.44$} & \multicolumn{3}{|c|}{${ }^{\mathrm{c}} R=.40$} & \multicolumn{2}{|c|}{${ }^{\mathrm{d}} R=.45}$. & \\
\hline & \multicolumn{3}{|c|}{$R^{2}=.18$} & \multicolumn{3}{|c|}{$R^{2}=.19$} & \multicolumn{3}{|c|}{$R^{2=} .16$} & \multicolumn{3}{|c|}{$R^{2=} .20$} \\
\hline & \multicolumn{3}{|c|}{$F=57.94, p<.05$} & \multicolumn{3}{|c|}{$F=61.92, p<.05$} & \multicolumn{3}{|c|}{$F=49.72, p<.05$} & \multicolumn{3}{|c|}{$F=66.59, p<.05$} \\
\hline
\end{tabular}

When Table 2 is examined, it is seen that both critical thinking disposition and problem solving skills have a significant relationship with efficacy for student engagement $(R=.42, p<.05)$. These predictor variables account for $18 \%$ of the variance in efficacy for student engagement. According to the results of regression analysis, efficacy for student engagement was positively and significantly predicted by critical thinking skills $(\beta=.23, p$ $<.05)$ and problem solving skills $(\beta=.23, p<.05)$.

In Table 2 , it is seen that the critical thinking disposition and problem solving skills have a significant relationship with efficacy for instructional strategies $(R=.44, p<.05)$. These predictor variables account for $19 \%$ of the variance in efficacy for student engagement. According to the results of the regression analysis, efficacy for student engagement was significantly and positively predicted by critical thinking disposition $(\beta=.26, p<.05)$ and problem solving skills $(\beta=.21, p<.05)$.

As can be seen in Table 2, critical thinking disposition and problem solving skills have a significant relationship with efficacy for classroom management $(R=.40, p<.05)$. These predictor variables account for $16 \%$ of the variance in efficacy for student engagement. According to the results of regression analysis, efficacy for student engagement was significantly and positively predicted by critical thinking disposition $(\beta=.13, p<.05)$ and problem solving skills $(\beta=.29, p<.05)$.

Lastly, as is also seen in Table 2, critical thinking disposition and problem solving skills have a significant relationship with teacher self-efficacy $(R=.45, p<.05)$. These predictor variables account for $20 \%$ of the variance for teacher self-efficacy. According to the results of the regression analysis, teacher self-efficacy was significantly and positively predicted by critical thinking skills $(\beta=.22, p<.05)$ and problem solving skills ( $\beta$ $=.26, p<.05)$.

\section{Discussion}

In this study, the relationships between pre-service teachers' critical thinking disposition, perceptions of problem solving skills, and teacher self-efficacy beliefs were examined. The findings confirm that critical thinking disposition and perceptions of problem-solving skills are important variables that predict teachers' self-efficacy beliefs.

Teacher self-efficacy beliefs of pre-service teachers were examined in the study. The pre-service teachers assessed themselves as quite competent at all levels in the sub-dimensions of self-efficacy. In other words, pre-service teachers thought they were competent in classroom management, instructional strategies and student engagement. There are findings reported in the literature that are parallel to the findings of this study (Ateş, 2016; Şahin-Taşkın \& Hacıömeroğlu, 2010; Baykara, 2011). The pre-service teachers' perceiving themselves as quite competent can be seen as an important result. Teachers with high self-efficacy beliefs make further efforts to improve student learning and achievement (Bergman, McLaughlin, Bass, Pauly, \& Zellman, 1977, Ruble, Usher \& McGrew, 2011). On the contrary, low self-efficacy beliefs in teachers cause different problems in the accomplishment of educational objectives (Henson, 2001; Tschannen-Moran \& Woolfolk-Hoy, 2001; Battersby \& Cave, 2014). Self-efficacy is related to professional experience (Egyed \& Short, 2006). In other words, experiences that require expertise have a vital importance in the development of self-efficacy (Bandura, 1977). In this study, although it is seen as a positive result that pre-service teachers have high self-efficacy beliefs, courses can be taught in education faculties to develop self-efficacy beliefs in teacher candidates. 
In the study, the pre-service teachers' critical thinking disposition was investigated. The preservice teachers' critical thinking disposition was not at an adequate level. There are findings in other studies that are consistent with the findings of this study (Alper, 2010; Can \& Kaymakci, 2015; Çetinkaya, 2011; Ekinci \& Aybek, 2010; Nalçac1, Meral, \& Şahin, 2016). It can be stated that analyticity, open-mindedness, cognitive maturity, curiosity, self-confidence, systematicity and searching for truth, which are important components of critical thinking, need to be improved in pre-service teachers. Pre-service teachers' low level of critical thinking disposition may be due to the contents of the undergraduate courses they take and not using different methods and techniques in these courses. In order to develop critical thinking skills, it is important for students to feel safe, reflect on how the thinking process works, be open to questions, ask quality questions, evaluate others' thoughts and evaluate their own thinking processes (Seferoğlu and Akbıyık, 2006). Critical thinking courses can be taught to candidate teachers in this respect. Trainings on teaching how to think are important to teach critical thinking skills (Brandt, 1985; cited in Seferoğlu \& Akbıyık, 2006). In addition, critical thinking requires rational, inquisitive and reflective thinking (Ennis, 1962). Thinking elements such as openness, accuracy, competence, depth, breadth, and certainty are important in critical thinking activities (Nosich, 2012). Therefore, changing teaching principles and methods, teaching critical thinking in a separate course or integrating it into another course, teaching staff's acting as a model for critical thinking can increase the disposition of pre-service teachers to think critically.

In the study, the pre-service teachers' perceptions of their problem solving skills were also examined. The re-service teachers' perceptions of problem solving skills seemed to be at a moderate level. In other words, the pre-service teachers did not feel strong enough in the problem-solving dimensions of self-confidence, approach-avoidance and personal control. Similar findings are also reported in the literature (Demirtaş \& Dönmez, 2008; Kışkır, 2011; N. Tok, Ş. Tok, \& Dolapçığlu, 2014). Considering the problems of the education system, it is expected that preservice teachers should have a high level of belief in solving the problems that they encounter. Thus, the problem solving capacities of pre-service teachers need to be improved. In problem-solving skills, coping with and defining problems, confidence in the solution, and cognitive processes are of great importance (Heppner \& Baker, 1997). It is known that cognitive processes are effective in problem solving (Gagne, 1985). Trainings aimed at improving problem solving skills may improve problem solving skills (Olgun, Onturk, Karabacak, Aslan, \& Serbest, 2010). Therefore, providing problem-solving opportunities for pre-service teachers will help them form their own cognitive strategies. It is possible to arrange courses on problem-solving skills in the curriculum of teacher training programs to enhance teacher candidates' problem-solving skills. In this respect, structured programs on problem-solving skills may be expected to improve the problem-solving skills of pre-service teachers.

Significant and positive correlations were revealed between the pre-service teachers' self-efficacy beliefs and critical thinking disposition. Similar findings can be found in the ltierature (Dehghani, Pakmehr, \& Malekzadeh, 2011; Kezer, Ogurlu, \& Akfirat, 2016; Phan, 2009; Zangenehvandi, Farahian, \& Gholami, 2014). At the same time, positive correlations were found between the pre-service teachers' problem-solving skills and teacher self-efficacy beliefs. Similar findings are also reported in other studies (Altunçekiç, Yaman, \& Koray, 2005; Aylar \& Aksin, 2011; Kesicioğlu \& Güven, 2014; Yenice, 2012). Due to the positive correlation between critical thinking and problem solving skills, a positive increase in critical thinking and problem solving can be said to increase the level of teacher self-efficacy beliefs or vice versa. As a result, it can be concluded that as pre-service teachers tend to think critically and their problem-solving skills become higher, they will be able to provide more student engagement, use classroom management strategies positively and employ instructional strategies to achieve higher levels of student learning. Accordingly, it can be argued that critical thinking and problem solving skills are important variables in increasing the level of teacher self-efficacy beliefs.

In the study, the predictor power of critical thinking and problem solving skills over teacher self-efficacy beliefs were examined. The results of the regression analysis revealed that efficacy for student engagement, efficacy for instructional strategies and efficacy for classroom management were predicted by critical thinking disposition and problem solving skills. There are similar findings about the role of critical thinking disposition (Zangenehvandi, Farahian, \& Gholami, 2014) and problem solving skills (Kesicioğlu \& Güven, 2014) in predicting teacher self-efficacy. According to these results, it is expected that pre-service teachers, whose critical thinking disposition and problem solving skills are sufficient, have a higher level of teacher self-efficacy beliefs. Critical thinking disposition and processing information effectively lead to problem solving (Seferoğlu \& Akbiyık, 2006). Pre-service teachers are expected to pursue rational strategies to become more effective teachers. As they increase their critical thinking and problem-solving skills, they will be more interested in the problems at school and will seek different ways to solve these problems, try different methods for student learning, and think critically about their work. It can be said that teachers who are active and motivated in their work will gain more 
successful experiences, and their self-efficacy beliefs will change in the positive direction by experiencing success. In problem-solving, understanding the nature of problems makes it easy to achieve the desired results (Bandura, 1986). Cognitive processing ability increases the level of work capacity and consequences (Truxillo, Seitz \& Bauer, 2008) and the ability to complete a task (Chen, Casper, \& Cortina, 2001; Cormier, Pickett-Hauber $\&$ Whyte, 2010). Thus, self-efficacy evolves in the positive direction (Chemers, Hu, \& Garcia, 2001). As a result, it is observed that the self-efficacy of pre-service teachers increase with their critical thinking disposition levels and their behaviors towards problem solving skills.

The significant results of the study can be summarized as follows: (i) Pre-service teachers seem to have a sufficient level of self-efficacy beliefs, a low level of critical thinking, and a moderate level of problem solving skills; (ii) Pre-service teachers' critical thinking disposition and problem solving skills are positively correlated with their teacher self-efficacy perceptions; (iii) Efficacy for student engagement, efficacy for strategies and efficacy for classroom management are predicted significantly and positively by critical thinking disposition and problem-solving skills. Consequently, different practices should be implemented in education faculties aiming at developing critical thinking disposition and problem solving skills of pre-service teachers. In this context, it may be useful to teach new courses for the development of thinking skills. At the same time, school practicum at education faculties can be implemented starting from the first year of the faculty to develop critical thinking and problem solving skills. Besides, pre-service teachers can be asked to produce projects for problems in education. In the courses, instructors can use different methods and techniques to make pre-service teachers more active in classes. Because critical thinking and problem-solving skills are important variables that determine self-efficacy, teachers at schools can be trained to think critically as well. Supporting qualitative methods such as interviews and observations, and gathering more detailed data can be useful for more descriptive results. Further studies may be carried out to gain a clearer understanding of the predictive power of critical thinking and problem solving skills over self-efficacy.

\section{References}

Alper, A. (2010). Öğretmen adaylarının eleştirel düşünme eğilimleri. Eğitim ve Bilim, 35(158), 14-27.

Altun, F. (2015). Müzik ögretmeni adaylarının öğrenme stilleri, problem çözme becerileri ve alan başarı puanları arasındaki ilişkiler (Yayımlanmamış yüksek lisans tezi). Eğitim Bilimleri Enstitüsü, İnönü Üniversitesi, Sivas.

Altunçekiç, A., Yaman, S., \& Koray, Ö. (2005). Öğretmen adaylarının öz-yeterlik inanç düzeyleri ve problem çözme becerileri üzerine bir araştırma (Kastamonu İli Örneği). Kastamonu Eğitim Dergisi, 13(1), 93-102.

Ateş, G. (2016). Adeniz üniversitesi eğitim fakültesi ögretmen adaylart ve Antalya'da görev yapan ögretmenlerin özyeterlik algılarının karşılaştırllması. (Yayımlanmamış yüksek lisans tezi). Akdeniz Üniversitesi, Antalya.

Aylar, F., \& Aksin, A. (2011). Sosyal bilgiler öğretmen adaylarının öz-yeterlilik inanç düzeyleri ve problem çözme becerileri üzerine bir araştırma (Amasya Örneği). Ahi Evran Üniversitesi Eğitim Fakültesi Dergisi, 12(3), 299-313.

Bandura, A. (1977). Social learning theory. NJ: Prentice-Hall.

Bandura, A. (1986). Social foundations of thought and action a social cognitive theory. New Jersey: Prentice-Hall.

Bandura, A. (1989). Human agency in social cognitive theory. American Psychologist, 44, 1175-1184. https://doi.org/10.1037/0003-066X.44.9.1175

Bandura, A. (1994). Self-efficacy. In V. S. Ramachaudran (Ed.), Encyclopedia of human behavior (Vol. 4, pp. 71-81). NY: Academic Press.

Battersby, S. L., \& Cave, A. (2014). Preservice classroom teachers' preconceived attitudes, confidence, beliefs, and self-efficacy toward integrating music in the elementary curriculum. Update: Applications of Research in Music Education, 32(2), 52-59. https://doi.org/10.1177/8755123314521033

Baykara, K. (2011). Öğretmen adaylarının biliş̧̈tesi öğrenme stratejileri ile öğretmen yeterlik algıları üzerine bir çalışma. Hacettepe Üniversitesi Eğitim Fakültesi Dergisi, 40(40), 80-92.

Belzer, K. D., D'Zurilla, T. J., \& Maydeu-Olivares, A. (2002). Social problem solving and trait anxiety as predictors of worry in a college student population. Personality and Individual Differences, 33(4), 573-585. https://doi.org/10.1016/S0191-8869(01)00173-8

Bergman, P., McLaughlin, M., Bass, M., Pauly, E., \& Zellman, G. (1977). Federal programs supporting 
educational change (Vol. VII). Factors affecting implementation and continuation. CA: RAND.

Beyer, B. (1987). Practical strategies for the teaching of thinking. Boston, MA: Allyn and Bacon.

Beyer, B. K. (1988). Developing a scope and sequence for thinking skills instruction. Educational Leadership, 45(7), 26-30.

Büyüköztürk, Ş. (2010). Sosyal bilimler için veri analizi el kitabı. Ankara: Pegem Akademi.

Çam, S., \& Tümkaya, S. (2007). Kişilerarası problem çözme envanteri’nin (KPÇE) geliştirilmesi: Geçerlik ve güvenirlik çalışması. Türk Psikolojik Danışma ve Rehberlik Dergisi, 28(3), 95-111.

Can, Ş., \& Kaymakçı, G. (2015). Öğretmen adaylarının eleştirel düşünme eğilimleri. e-Journal of New World Sciences Academy, 10(2), 65-83. doi:10.12739/nwsa.2015.10.2.1c0633

Çapa, Y., Çakıroğlu, J., \& Sarıkaya, H. (2005). Öğretmenlik öz-yeterlik ölçeğinin Türkçe uyarlamasının geçerlik ve güvenirlik çalışması. Eğitim ve Bilim, 30(137), 74-81.

Çetinkaya, Z. (2011). Türkçe öğretmen adaylarının eleştirel düşünmeye ilişkin görüşlerinin belirlenmesi. Ahi Evran Üniversitesi Kırşehir Eğitim Fakültesi Dergisi, 12(3), 93-108.

Chemers, M. M., Hu, L. T., \& Garcia, B. F. (2001). Academic self-efficacy and first year college student performance and adjustment. Journal of Educational psychology, 93(1), 55-64. https://doi.org/10.1037//0022-0663.93.1.55

Chen, G., Casper, W. J., \& Cortina, J. M. (2001). The roles of self-efficacy and task complexity in the relationships among cognitive ability, conscientiousness, and work-related performance: A meta-analytic examination. Human Performance, 14(3), 209-230. https://doi.org/10.1207/S15327043HUP1403

Cormier, E. M., Pickett-Hauber, R., \& Whyte, J. (2010). Cognitions and clinical performance: a comparison of high and low performing baccalaureate nursing students. International Journal of Nursing Education Scholarship, 7(1). https://doi.org/10.2202/1548-923x.2045

Cüceloğlu, D. (1994). İyi düşün doğru karar ver. İstanbul: Sistem Yayıncılık.

D’Zurilla, T. J., \& Nezu, A. M. (1987). The Heppner and Krauskopf Approach: A model of personal problem solving or social skills? Journal of Counseling Psychology, 15(3), 463-470. https://doi.org/10.1177/0011000087153005

Dam, T. G., \& Volman, M. (2004). Critical thinking as a citizenship competence: Teaching strategies. Learning and Instruction, 14(4), 359-379. https://doi.org/10.1016/j.learninstruc.2004.01.005

Dehghani, M., Pakmehr, H., \& Malekzadeh, A. (2011). Relationship between Students' critical thinking and self-efficacy beliefs in Ferdowsi University of Mashhad, Iran. Procedia-Social and Behavioral Sciences, 15, 2952-2955. https://doi.org/10.1016/j.sbspro.2011.04.221

Demirtaş, H., \& Dönmez, B. (2008). Secondary school teachers' perceptions about their problem solving abilities. Journal of the Faculty of Education, 9(16), 177-198.

Demirtaş, H., \& Güneş, H. (2002). Eğitim yönetimi ve denetimi sözlüğ̈̈. Ankara: Anı yayıncılık.

Egyed, C. J., \& Short, R. J. (2006). Teacher self-efficacy, burnout, experience and decision to refer a disruptive student. School Psychology International, 27(4), 462-474. https://doi.org/10.1177/0143034306070432

Ekinci, Ö., \& Aybek, B. (2010). Öğretmen adaylarının empatik ve eleştirel düşünme eğilimlerinin incelenmesi. Illköğretim Online, 9(2), 816-827.

Ennis, R. H. (1962). Concept of critical thinking. Harvard Educational Review, 32(1), 81-111.

Ennis, R. H. (1985). A logical basis for measuring critical thinking skills. Educational Leadership, 43(2), 44-48.

Facione, P. A. (1990). The California critical thinking skills test-College level. Technical report \#2. Factors predictive of CT skills. CA: California Academic Press.

Facione, P., Facione, N., \& Giancarlo, C. (1996). The motivation to think in working and learning. In E. Jones (Ed.), Defining Expectations for Student Learning. San Francisco, CA: Jossey-Bass Inc. https://doi.org/10.1002/he.36919969608

Facione, P. A., Facione, N. C., \& Giancarlo, C. A. F. (1998). The California Critical Thinking Disposition Inventory. California: Academic Press.

Ford, T. G., Van Sickle, M. E., Clark, L. V., Fazio-Brunson, M., \& Schween, D. C. (2017). Teacher self-efficacy, 
professional commitment, and high-stakes teacher evaluation policy in Louisiana. Educational Policy, 31(2), 202-248. https://doi.org/10.1177/0895904815586855

Gagné, R. (1985). The conditions of learning and theory of instruction (4th ed.). Florida: Holt, Rinehart and Winston, Inc.

Gloudemans, H. A., Schalk, R. M. J. D., \& Reynaert, W. (2013). The relationship between critical thinking skills and self-efficacy beliefs in mental health nurses. Nurse Education Today, 33(3), 275-280. https://doi.org/10.1016/j.nedt.2012.05.006

Güçlü, N. (2003). Lise müdürlerinin problem çözme becerileri. Milli Eğitim Dergisi, 160.

Henson, K. (2001). Relationships between pre-service teachers' self-efficacy, task analysis, and classroom management beliefs. Paper presented at the annual meeting of the southwest educational research association, New Orleans.

Heppner, P. P., \& Baker, C. E. (1997). Applications of the problem solving nnventory. Measurement \& Evaluation in Counseling \& Development, 29(4), 229-313.

Heppner, P. P., \& Petersen, C. H. (1982). The development and implications of a personal problem-solving inventory. Journal of Counseling Psychology, 29(1), 66. https://doi.org/10.1037/0022-0167.29.1.66

Heppner, P. P., \& Krauskopf, C. J. (1987). An information processing apporach to personal problem solving, The Counseling Psychologist, 15(3), 371-447. https://doi.org/10.1177/0011000087153001

Hudlicka, E. (2005). Modeling interaction between metacognition and emotion in a cognitive architecture. In Proceedings of the AAAI Spring Symposium on Metacognition in Computation (pp. 55-61). Menlo Park, CA: AAAI Press.

Kantek, F., Öztürk, N., \& Gezer, N. (2010). Bir Sağllk Yüksekokulunda Öğrencilerin Eleştirel Düşünme Ve Problem Çözme Becerilerinin Incelenmesi. In International Conference on New Trends in Education and Their Implications (pp. 186-190). Antalya, Türkiye.

Kapa, E. (2001). A metacognitive support during the process of problem solving in a computerized environment. Educational Studies in Mathematics, 47(3), 317-336. https://doi.org/10.1023/A:1015124013119

Kazanc1, O. (1989). Eğitimde eleştirici düşünme ve öğretimi. Ankara: Kazancı Kitap.

Kesicioğlu, O. S., \& Güven, G. (2014). Okul öncesi öğretmen adaylarının özyeterlik düzeyleri ile problem çözme, empati ve iletişim becerileri arasındaki ilişkinin incelenmesi. Turkish Studies, 9(5), 1371-1383. https://doi.org/10.7827/TurkishStudies.6784

Kezer, F., Oğurlu, Ü., \& Akfirat, O. N. (2016). Eleştirel düşünme eğilimi, genel öz yeterlik ve umutsuzluk arasındaki ilişkinin incelenmesi. Mustafa Kemal Üniversitesi Sosyal Bilimler Enstitüsü Dergisi, 13(34), 202-218.

Kışkır, G. (2011). Öğretmen adaylarının bilişötesi farkındalık düzeyleri ile problem çözme becerileri arasındakı ilişskinin incelenmesi (Yayımlanmamış Yüksek Lisans Tezi). Atatürk Üniversitesi Eğitim Bilimleri Enstitüsü, Erzurum.

Kökdemir, D. (2003). Belirsizlik durumlarında karar verme ve problem çözme (Yayımlanmamış doktora tezi), Ankara Üniversitesi, Sosyal Bilimler Enstitüsü. Ankara.

Main, S., \& Hammond, L. (2008). Best practice or most practiced? pre-service teachers' beliefs about effective behaviour management strategies and reported self-efficacy. Australian Journal of Teacher Education, 33(4). https://doi.org/10.14221/ajte.2008v33n4.3

Manalo, E., Kusumi, T., Koyasu, M., Michita, Y., \& Tanaka, Y. (2013). To what extent do culture-related factors influence university students' critical thinking use? Thinking Skills and Creativity, 10, 121-132. https://doi.org/10.1016/j.tsc.2013.08.003

Marri, A. R., Ahn, M., Fletcher, J., Heng, T. T., \& Hatch, T. (2012). Self-efficacy of US high school teachers teaching the federal budget, national debt and budget deficit: A mixed-method case research. Citizenship, Social and Economics Education, 11(2), 105-121. https://doi.org/10.2304/csee.2012.11.2.105

Morgan, C. T. (1991). Psikolojiye Giriş (Çev. Karataş S.), Hacettepe Üniversitesi, Psikoloji Bölümü Yayınları, Ankara.

Nalçacı, A., Meral, E., \& Şahin, İ. F. (2016). Sosyal bilgiler öğretmen adaylarının eleştirel düşünme ile medya okuryazarlıkları arasındaki ilişki. Doğu Coğrafya Dergisi, 21(36), 1-12. https://doi.org/10.17295/dcd.99051 
Norris, S. P. (1994). The meaning of critical thinking test performance: The effects of abilities and disposition on scores. In D. Fasko (Ed.), Critical thinking: Current research, theory, and practice. The Netherlands: Kluwer.

Nosich, M. N. (2012). Eleştirel düşünme ve disiplinlerarası eleştirel düşünme rehberi (Çev. Birsel Aybek). Ankara: Anı yayınları:

Oğuztürk, Ö., Akça, F., \& Şahin, G. (2011). Üniversite öğrencilerinde umutsuzluk düzeyi ile problem çözme becerileri arasındaki ilişkinin bazı değişkenler üzerinden incelenmesi. Klinik Psikiyatri Dergisi, 14(3).173-184.

Olgun, N., Öntürk, Z. K., Karabacak, U., Aslan, F. E., \& Serbest, S. (2010). Problem solving skills of the nursing students: Results of the 1-year observation problem solving skills of the students. Journal of Acrbadem University Health Science, 1(4), 188-194.

Özden Y. (2000). Öğrenme ve ögretme. Ankara: PegemA

Özerkan, E. (2007). Öğretmenlerin öz-yeterlik algıları ile ögrencilerin sosyal bilgiler benlik kavramları arasındaki ilişki (Yayımlanmamış yüksek lisans tezi). Trakya Üniversitesi, Edirne.

Paul, R., \& Elder, L. (2008). The miniature guide to critical thinking concepts and tools. CA: Foundation for Critical Thinking Press.

Phan, H. P. (2009). Relations between goals, self-efficacy, critical thinking and deep processing strategies: A path analysis, Educational Psychology, 29(7), 777-799. https://doi.org/10.1080/01443410903289423

Ruble, L. A., Usher, E. L., \& McGrew, J. H. (2011). Preliminary investigation of the sources of self-efficacy among teachers of students with autism. Focus on Autism and Other Developmental Disabilities, 26(2), 67-74. https://doi.org/10.1177/1088357610397345

Şahin, N., Şahin, N. H., \& Heppner, P. P. (1993). Psychometric properties of the problem solving inventory in a group of Turkish university students. Cognitive Therapy and Research, 17(4), 379-396. https://doi.org/10.1007/BF01177661

Şahin-Taşkın, Ç., \& Hacıömeroğlu, G. (2010). Sınıf öğretmeni adaylarının özyeterlik inançları: Nicel ve nitel verilere dayalı bir inceleme. İn̈̈n̈̈ Üniversitesi Eğitim Fakültesi Dergisi, 11, 21-40.

Seferoğlu, S. S., \& Akbıyık, C. (2006). Eleştirel düşünme ve öğretimi. Hacettepe Üniversitesi Eğitim Fakültesi Dergisi, 30(30), 193-200.

Şencan, H. (2005). Sosyal ve davranışsal ölçümlerde güvenilirlik ve geçerlilik. Ankara: Seçkin.

Srisawad, K., Ratanaolarn, T., \& Kiddee, K. (2016). The development of structural equation model of critical thinking among nursing students. Walailak Journal of Science and Technology (WJST), 14(1), 65-73.

Tishman, S., Jay, E., \& Perkins, D. N. (1993). Teaching thinking dispositions: From transmission to enculturation. Theory into Practice, 32(3), 147-153. https://doi.org/10.1080/00405849309543590

Tok, T. N., Tok, Ş., \& Dolapçıŏlu, S. D. (2014). The perception levels of the novice teachers' problem-solving skills. Procedia-Social and Behavioral Sciences, 116, 415-420. https://doi.org/10.1016/j.sbspro.2014.01.232

Truxillo, D. M., Seitz, R., Bauer, T. N. (2008). The role of cognitive ability in self-efficacy and self-assessed test performance. Journal of Applied Social Psychology, 38(4), 903-918. https://doi.org/10.1111/j.1559-1816.2008.00331.x

Tschannen-Moran, M., \& Woolfolk-Hoy, A. (2001). Teacher efficacy: Capturing an elusive construct. Teaching and Teacher Education, 17(7), 783-805. https://doi.org/10.1016/S0742-051X(01)00036-1

Tschannen-Moran, M., Hoy, A. W., \& Hoy, W. K. (1998). Teacher efficacy: Its meaning and measure. Review of Educational Research, 68(2), 202-248. https://doi.org/10.3102/00346543068002202

Varandi, S. B., \& Mehrali, S. (2013). Investigating the effect of levels of proficiency on Iranian male and female EFL learners' critical thinking and self-efficacy. Theory and Practice in Language Studies, 3(12), 2355. https://doi.org/10.4304/tpls.3.12.2355-2361

Viel-Ruma, K., Houchins, D., Jolivette, K., \& Benson, G. (2010). Efficacy beliefs of special educators: The relationsihp among collective eficacy, teacher self-efficacy and job satisfaction. Teacher education and special education, 33(3), 225-233. https://doi.org/10.1177/0888406409360129

Woolfolk, A., \& Hoy, W. (1990). Prospective teachers' sense of efficacy and beliefs about control. Journal of 
Educational Psychology, 82, 81-91. https://doi.org/10.1037/0022-0663.82.1.81

Yenice, N. (2012). Öğretmen adaylarinin öz-yeterlik düzeyleri ile problem çözme becerilerinin incelenmesi. Elektronik Sosyal Bilimler Dergisi, 11(39), 36-58.

Zangenehvandi, M., Farahian, M., \& Gholami, H. (2014). On the relationship between EFLteachers'critical thinking and self-efficacy. Modern Journal of Language Teaching Methods, 4(2), 286-293.

Zee, M., \& Koomen, H. M. Y. (2010). Teacher self-efficacy and its effects on classroom processes, student academic adjustment, and teacher well-being: A synthesis of 40 years of research. Review of Educational Research, 20(10), 1-35. https://doi.org/10.3102/0034654315626801

Zhang, L. F. (2003). Contributions of thinking styles to critical thinking disposition. Journal of Psychology, 137(6), 517-543. https://doi.org/10.1080/00223980309600633

\section{Copyrights}

Copyright for this article is retained by the author(s), with first publication rights granted to the journal.

This is an open-access article distributed under the terms and conditions of the Creative Commons Attribution license (http://creativecommons.org/licenses/by/4.0/). 